\title{
STRUCTURAL ELUCIDATION OF BIOACTIVE PRINCIPLES IN FLORAL EXTRACTS OF GERMAN CHAMOMILLE (MATRICARIA RECUTITA L.)
}

\author{
G. E. BUONO-CORE, ${ }^{* 1}$ M. VANESSA NUÑEZ, ${ }^{1}$ ANDREA LUCERO,${ }^{1}$ ROBINSON VARGAS M., ${ }^{2}$ \\ CAROLINA JULLIAN ${ }^{3}$
}

\author{
${ }^{1}$ Instituto de Química, Pontificia Universidad Católica de Valparaíso, Casilla 4059, Valparaíso, CHILE \\ ${ }^{2}$ Centro Experimental de Entomología La Cruz, INIA, Casilla 3, La Cruz, CHILE \\ ${ }^{3}$ Departamento de Química Orgánica y Físico-Química, Facultad de Ciencias Químicas y Farmacéuticas, Universidad de Chile, Casilla 233, Santiago, CHILE
}

(Received: October 7, 2010 - Accepted: February 28, 2011)

\begin{abstract}
In this work, bioactive compounds present in flower heads of German Chamomille, were extracted and isolated in pure forms by chromatographic techniques. These compounds, spiroketal enol ethers, present in both isomeric forms $\boldsymbol{Z}$ and $\boldsymbol{E}$, were characterized and unequivocally identified by spectroscopic techniques. One- $\left({ }^{1} \mathrm{H},{ }^{13} \mathrm{C}\right)$ and two-dimensional $\left({ }^{1} \mathrm{H}-{ }^{1} \mathrm{H}-\mathrm{COSY},{ }^{1} \mathrm{H}-{ }^{1} \mathrm{H}-\mathrm{NOESY}, \mathrm{HMQC}\right.$ and $\left.\mathrm{HMBC}\right)$ NMR were used to assign the configuration of each isomeric compound. It was also found that irradiation of the extracts with UV light induced the photoisomerization of the en-yn-dicycloethers favoring the formation of the more stable $\boldsymbol{E}$ isomer.
\end{abstract}

Keywords: Spiroketal enol ethers, German Chamomille, NMR spectra, NOESY

\section{INTRODUCTION}

The German Chamomille (Matricaria recutita L), a plant belonging to the Asteraceae family, is considered by many as one of the most important of the medicinal plants, due to its anti-inflammatory, anti-espasmodic, antiallergenic, anti-bacterial and fungicidal properties. ${ }^{1}$ The sanation power of this herb is due to the result of the interaction of many of its components. Close to 120 secondary metabolites have been identified in Chamomille, including 28 terpenoids, 36 flavonoids and 52 additional components, all of them with potential pharmacological activity. ${ }^{2-5}$

The toxicological activity of the main constituents present in flower heads of Chamomille is currently under investigation. It has been found that the ovogenesis of domestic flies (Musca domestica L.) is seriously affected when adult states of this insect are topically treated with essential oil obtained from Chamomille flowers. ${ }^{6}$

One of the metabolites found in Chamomille flowers is the en-yndicycloether (Fig. 1), to which most of the antiinflamatory properties of this herb have been attributed. ${ }^{7}$ This compound has also been found in floral extracts of the species Chrysanthemum coronarium, which have shown an important acaricidal and insecticidal activity. ${ }^{8}$ Bioessays performed on mites (Tetranychus urticae K.) and insects (Musca domestica L.) have shown that the en-yn-dicycloether is one of the active principles responsible for the lethal (mortality) and sub-lethal (repellence, irritance, antifeeding) effects shown by floral extracts of Chrysanthemum coronarium. ${ }^{8}$

In this work, the separation, characterization and identification of the enyn-dicycloethers found in flower heads of Matricaria recutita is described.

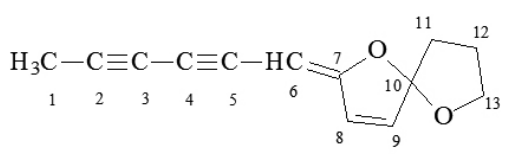

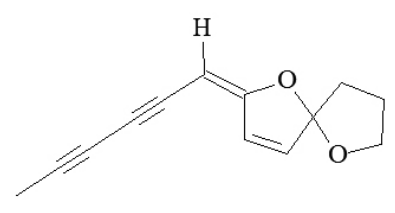

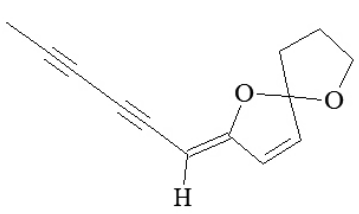

E

Figure 1. Structure of en-yn-dicycloether and its isomers $E$ and $Z$

\section{EXPERIMENTAL}

General experimental procedures

Gas chromatographic analysis was performed on a Hewlett-Packard 5790A chromatograph equipped with a split-splitless injector and a flame-ionization detector, and connected to a LDC Analytical D-2500 integrator for storing and replotting of the data. A fused silica capillary column $(30 \mathrm{~m}, 0.25 \mathrm{~mm}$ i.d.) coated with a $0.25 \mathrm{~mm}$ film of cross-linked $5 \%$ phenyl methyl silicone (Supelco SE-54) was used with helium $(1 \mathrm{ml} / \mathrm{min})$ as the carrier gas. In a typical analysis, the column oven was held for $2 \mathrm{~min}$ at $80^{\circ} \mathrm{C}$, then programmed at $10^{\circ} \mathrm{C} / \mathrm{min}$ to $250^{\circ} \mathrm{C}$ and held for $10 \mathrm{~min}$. Injector and detector temperature was $250^{\circ} \mathrm{C}$. Identification of extract components was achieved using a mass selective detector (Shimadzu MS-QP5050-A) coupled to a gas chromatography system (Shimadzu GC-17A Series) under chromatographic conditions as described above. Structural elucidation was achieved by searching a database (Masslab, NIST, Wiley) of spectra using a probability based matching algorithm. Further identification of components in the Chamomille extract was based on $\mathrm{GC}$ retention indices (RI) relative to n-alkanes and were in general in good agreement with the literature. ${ }^{9,10}$

NMR analyses were carried out at CEPEDEQ, Facultad de Ciencias Químicas y Farmacéuticas, Universidad de Chile. Proton and Carbon nmr spectra were acquired using a Bruker AVANCE DRX 300 spectrometer operating at a proton frequency of $300.13 \mathrm{MHz}$ and $75.47 \mathrm{MHz}$ respectively. All measurements were performed at a probe temperature of $300^{\circ} \mathrm{K}$, using solutions of isomers $\boldsymbol{E}$ and $\boldsymbol{Z}$ in $\mathrm{CDCl}_{3}$ containing tetramethylsilane (TMS) as an internal standard. All one and two-dimensional spectra were acquired with a Bruker inverse $5 \mathrm{~mm} \mathrm{Z}$ gradient probe. ${ }^{1} \mathrm{H}$ spectra were obtained with a spectral width of $2300 \mathrm{~Hz}$, a $90^{\circ}$ flip angle $(9.5 \mathrm{~ms})$ and $2 \mathrm{~s}$ relaxation delay in 16 scans. The one-dimensional carbon spectrum was obtained with a spectral width of $15000 \mathrm{~Hz}$ with 3 seconds between transients and the $90^{\circ}$ pulse was $10 \mathrm{~ms}$. The HMQC spectra were performed using standard Bruker software (inv4gstp). These spectra were collected with $512 \times 512$ data points, a data adquisition of 4 scans $\mathrm{x} F$ and 256 increments in $\mathrm{t}$. Spectral widths of $2300 \mathrm{~Hz}$ and $15000 \mathrm{~Hz}$ were employed in the $F_{2}\left({ }^{1} \mathrm{H}\right)$ and $F_{I}\left({ }^{13} \mathrm{C}\right)$ domains, respectively. Data were processed using Qsine functions for weighting in both dimensions. The HMBC spectra were obtained using the inv4gslplrnd pulse sequence in the Bruker software. The spectral widths were $2300 \mathrm{~Hz}\left(F_{2}\right)$ and $18000 \mathrm{~Hz}\left(F_{l}\right)$ and delays $\mathrm{D}_{1}$ y $\mathrm{D}_{2}$ were set to 3.45 and $65 \mathrm{~ms}$, respectively. Data were processed using an exponential window in $F$, with $\mathrm{lb}=5 \mathrm{~Hz}$ and Qsine window in $F_{l}$. The NOESY spectra were recorded in the phase-sensitive mode, over the same $2300 \mathrm{~Hz}$ spectral window; $1 \mathrm{~K}$ points over 256 increments were collected in 16 transients, with a mixing time of $0.8 \mathrm{~s}$. The FID were processed by sinusoidal multiplication in each dimension.

IR spectra were determined as films on $\mathrm{NaCl}$ cells in a Perkin-Elmer FTIR Model 1605. UV spectra were obtained in $1 \mathrm{~cm}$ quartz cells in a Hewlett- 
Packard 8452-A diode array spectrophotometer.

\section{Preparation of the extracts.}

Flowers of Matricaria recutita L., were collected during the months of September through December from an area $20 \mathrm{~km}$ north of Valparaiso. The plant was authenticated by Professor Otto Zöellner (Biology Institute, Pontificia Universidad Católica de Valparaiso). Flower buds were dried for 3 days in green houses provided by the Centro Experimental de Entomología La Cruz, then ground in a Moulinex mill, and stored in glass containers in a cold room $\left(\right.$ at $\left.5^{\circ} \mathrm{C}\right)$.

Portions of powdered dried flowers were extracted with hexane (GR, Merck). In a typical extraction procedure, $120 \mathrm{~g}$ of plant material was continuously extracted with $1.2 \mathrm{~L}$ of hexane for 4 hours in a Soxhlet extractor. After filtration and evaporation of solvent, a dark yellow viscous extract is obtained. Refining is carried out by adding to this crude extract methanol (in a $1: 25 \mathrm{v} / \mathrm{v}$ ) and stirring the mixture during 2 hours at $-70{ }^{\circ} \mathrm{C}$ using a dry iceisopropanol bath. Filtration and evaporation of the methanol gives an extract which is yellow and liquid at room temperature. The refining step is required in order to remove vegetable waxes and resins present in the crude extract. This refined extract was used for chromatographic analysis and separation of the bioactive compounds.

\section{Chromatographic separation of the refined extracts.}

Flash chromatography techniques were used for the separation of the isomers from the refined extracts. ${ }^{11}$ The first separation was carried out using a glass column ( 29 inches long x $40 \mathrm{~mm}$ i.d.) packed with silica gel $60(0.040-$ $0.063 \mathrm{~mm}$, Merck), with an eluent consisting of $15 \%$ ethyl acetate/hexane. A volume of $850 \mathrm{ml}$ were eluted at a rate of $2 \mathrm{in} / \mathrm{min}$ with a flow of nitrogen, and 29 fractions $\left(30 \mathrm{ml}\right.$ each) were collected. TLC analysis (silica gel $60 \mathrm{~F}_{254}$, Merck) was performed on each fraction and these data was used to combine some of these fractions into three main fractions. Fractions 11-15 gave rise to Fraction I $(102 \mathrm{mg})$, fractions $18-22$ to Fraction II $(56 \mathrm{mg})$ and fractions $24-29$ to Fraction III $(47 \mathrm{mg})$. A GC-MS analysis showed that Fraction I contains only one isomer (Peak $\mathrm{N}^{\circ} 6$ in Fig. 2) in a $75 \%$ while Fraction II contains both isomers (Peak $\mathrm{N}^{\circ} 6$ and Peak $\mathrm{N}^{\circ} 7$ in Fig. 2) in a $4.5 \%$ and $84.4 \%$, respectively. Analysis of Fraction III also showed the presence of both isomers, but with a low $\%(<12 \%)$, and therefore this fraction was not used for further separation.

Each fraction, I and II, was flash chromatographed using a glass column (24 inches long x $30 \mathrm{~mm}$ i.d.) packed with silica gel $60(0.040-0.063 \mathrm{~mm}$, Merck), with 10\% ethyl acetate/hexane as the eluent. For Fraction I (360 mg), $400 \mathrm{ml}$ of eluent were used, with a nitrogen flow rate of $2 \mathrm{in} / \mathrm{min}$, and 22 fractions $(20 \mathrm{ml}$ each) were collected. After TLC and GC analysis, $70 \mathrm{mg}$ of Isomer I were obtained with a $93 \%$ GC purity. EI-MS (rel. int.) $200\left(100, \mathrm{M}^{+}\right)$, 185 (22), 170 (19), 157 (32), 115 (62), 55 (54), 54 (57); ${ }^{1} \mathrm{H}$ and ${ }^{13} \mathrm{C}$ NMR: see Table 2. For Fraction II (215 mg), $650 \mathrm{ml}$ of eluent were used with a nitrogen flow rate of $2 \mathrm{in} / \mathrm{min}$, and 35 fractions $(20 \mathrm{ml}$ each) were collected. After the corresponding TLC and GC analysis of the fractions, $47 \mathrm{mg}$ of Isomer II were obtained with a $95 \%$ GC purity. EI-MS (rel. int.) $200\left(100, \mathrm{M}^{+}\right), 185(20), 170$ (23), 157 (28), 115 (53), 55 (53), 50 (49); ${ }^{1} \mathrm{H}$ and ${ }^{13} \mathrm{C}$ NMR: see Table 3.

\section{UV light effect}

Solutions of the refined Chamomille extract $(0.1 \% \mathrm{w} / \mathrm{v})$, Isomer $\boldsymbol{Z}(0.04 \%$ $\mathrm{w} / \mathrm{v})$ and Isomer $\boldsymbol{E}(0.03 \% \mathrm{w} / \mathrm{v})$ in methanol (GR, Merck) were prepared, and irradiated in pyrex tubes in a Rayonet RPR-100 photoreactor equipped with 8 lamps of $300 \mathrm{~nm}$ and 8 lamps of $350 \mathrm{~nm}$. The solutions were irradiated for 25 $\mathrm{min}$, and samples were taken out at time intervals $(5 \mathrm{~min}$ each for the isomers and $1 \mathrm{~min}$ for the extract) to be monitored by gas chromatography.

\section{RESULTS AND DISCUSSION}

Separation of the en-yn-dicycloether isomers

The crude extract yield of Matricaria recutita L. upon continuos extraction with hexane was $2.5 \%$ based on weight of dried flowers. The yield of the refined extract after purification with methanol at low temperature was $0.9 \%$. A chemical profile of the extract was obtained by gas chromatography-mass spectrometry analysis (Fig. 2, Table 1). This revealed that the main components of the Chamomille extract are $\alpha$-bisabolol oxide A $(7.2 \%)$, palmitic acid (15.9\%), 9,12-octadecadien-1-ol (24.9\%) and 2-(2,4-hexadiinilidene)-1,6dioxaspiro[4,4]non-3-ene (12.3 and $3.9 \%)$. This last compound, also known as en-yn-dicycloether, is present in two isomeric forms, as shown by the mass spectra of peaks 6 and 7 in the chromatogram (Fig. 2). Both spectra showed the same molecular ion peak at $\mathrm{m} / \mathrm{e} 200$, and identical fragmentation pattern, which indicates that both isomers of the en-yn-dicycloether, $\boldsymbol{E}$ and $\boldsymbol{Z}$, are present in the Chamomille extract.

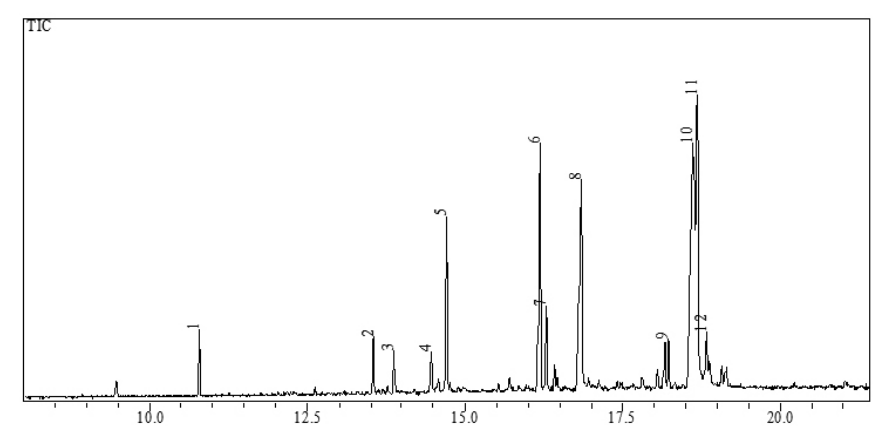

Figure 2. Gas chromatography of a floral extract of Matricaria recutita L. (see conditions in experimental part).

In order to separate, isolate and identify the en-yn-dicycloether isomers, the refined extract was subjected to flash chromatography on silica gel, using a combination of ethyl acetate/hexane mixtures. With a first chromatography using $15 \%$ ethyl acetate/hexane, two fractions containing the isomers in a $75.4 \%$ and $84.5 \%$ purity were obtained. A third fraction also containing both isomers $(<12 \%)$, showed the presence of many other compounds, and therefore this fraction was not used. Further separation of fractions I and II using 10\% ethyl acetate/hexane allowed the obtention of each isomer with a purity of $93 \%$ (Isomer I) and 95\% (Isomer II).

Table 1. List of components of a refined floral extract of German Chamomille, tentatively identified by gas chromatography/mass spectrometry.

\begin{tabular}{|c|c|c|c|}
\hline Peak N & Compound name & RI & Relative \% \\
\hline 1 & $(E)(Z)$ - $\beta$-farnesene & 1455 & 2.4 \\
\hline 2 & $\alpha$-bisabolol oxide B & 1676 & 2.3 \\
\hline 3 & $\alpha$-bisabolol & 1705 & 1.9 \\
\hline 4 & 7-methoxycoumarin & 1758 & 2.0 \\
\hline 5 & $\alpha$-bisabolol oxide A & 1779 & 7.2 \\
\hline 6 & $\begin{array}{c}\text { 2-(2,4-hexadiinylydene)-1,6- } \\
\text { dioxaspyro[4,4]non-3-ene }\end{array}$ & 1911 & 12.3 \\
\hline 7 & $\begin{array}{c}\text { 2-(2,4-hexadinylydene)-1,6- } \\
\text { dioxaspyro[4,4]non-3-ene }\end{array}$ & 1920 & 3.9 \\
\hline 8 & palmitic acid & 1969 & 15.9 \\
\hline 9 & N.N. & - & 4.1 \\
\hline 10 & $9,12-o c t a d e c a d i e n-1-o l$ & 2031 & 24.9 \\
\hline 11 & N.N. & - & 20.3 \\
\hline 12 & N.N. & - & 2.9 \\
\hline
\end{tabular}

RI, retention indexes (DB-5 column), for hydrocarbons according to Kovats

N.N. $=$ unknown (less than $80 \%$ probability from spectra database)

Spectroscopic Analysis of Isomers I and II.

${ }^{1} H$ NMR and ${ }^{13} C$ NMR spectral studies.

Isomer I. The ${ }^{1} \mathrm{H}-\mathrm{NMR}$ spectrum of I showed two singlets corresponding to the methyl group (d 1.99) and to H-6 of the exocyclic double bond (d 4.59). Two doublets observed at 6.23 and $6.15 \mathrm{ppm}$, with the same coupling constants $(\mathrm{J}=5.68 \mathrm{~Hz})$ can be assigned to the protons of the endocyclic double bond, $\mathrm{H}-8$ and $\mathrm{H}-9$. The methylenic protons appeared as multiplets resonating at 2.05$2.22,2.05-2.31$ and 4.0 and $4.21 \mathrm{ppm}$. This latter resonance can be assigned straightforward to the $\mathrm{H}-13$ protons since these are bonded to a carbon bonded 
to oxygen, and therefore deshielded with respect to the other methylenic protons.

The ${ }^{13} \mathrm{C}$ spectrum shows a signal resonating at $5.14 \mathrm{ppm}$ corresponding to $\mathrm{C}-1$. At downfield a signal is observed at $\mathrm{d} 167.6$ which should correspond to a highly deshielded carbon such as the olefinic C-7. A low intensity signal resonating at $121.5 \mathrm{ppm}$ was assigned to the spiro $\mathrm{C}-10$, also deshielded by the presence of two electronegative oxygen atoms.

The methyl, methylene, and methine carbon signals for isomer I were also assigned by using a HMQC sequence technique. These data are shown in Table 2. The HMQC spectrum showed that the proton resonating at $1.99 \mathrm{ppm}$ $(\mathrm{H}-1)$ is one-bond connected with the carbon resonating at $5.14 \mathrm{ppm}(\mathrm{C}-1)$, while the proton resonating a $4.59 \mathrm{ppm}(\mathrm{H}-6)$ is connected with the carbon resonating at $79.17 \mathrm{ppm}(\mathrm{C}-6)$. On the other hand, H-8 (6.23 ppm) and H-9 $(6.15 \mathrm{ppm})$ correlate directly with carbons resonating at 127.8 and $135.7 \mathrm{ppm}$, respectively. The heterocyclic ring methylenic protons, $\mathrm{H}-11, \mathrm{H}-12$ and $\mathrm{H}-13$, show direct correlation with the carbons C-11 (35.99 ppm), C-12 (24.87 ppm) and C-13 (70.08 ppm), respectively.

The HMBC spectrum shows long-range correlations between $\mathrm{H}-6$ and five carbon resonances, at $167.6 \mathrm{ppm}$ (C-7), $127.8 \mathrm{ppm}(\mathrm{C}-8), 79.26 \mathrm{ppm}(\mathrm{C}-4)$, 71.16 (C-5) and 65.67 (C-3). Since no long-range correlation was observed between $\mathrm{H}-6$ and the carbon resonating at $80.99 \mathrm{ppm}$, this chemical shift was assigned to the acetylenic carbon $\mathrm{C}-2$.

Table 2. ${ }^{1} \mathrm{H}$ and ${ }^{13} \mathrm{C}$ NMR of $(Z)$ en-yn-dicycloether (Isomer I).

\begin{tabular}{|c|c|c|c|c|}
\hline $\begin{array}{l}\text { Carbon } \\
\mathrm{N}^{\circ}\end{array}$ & $\begin{array}{l}\text { Chemical shift }{ }^{*}, \delta \\
{[\mathrm{H}-\mathrm{X}, \mathrm{multiplicity,} \mathrm{J}} \\
(\mathrm{H}, \mathrm{H}) \mathrm{Hz}]\end{array}$ & $\begin{array}{l}{ }^{13} \mathrm{C} \\
\mathrm{ppm}\end{array}$ & $\begin{array}{l}\text { HMQC } \\
\mathrm{J}(\mathrm{C}, \mathrm{H})\end{array}$ & $\begin{array}{c}\text { Protons } \\
\text { showing } \\
\text { HMBC } \\
\text { correlation } \\
{[\text { coupling] }]^{3} \mathrm{~J}} \\
(\mathrm{C}-\mathrm{H})\end{array}$ \\
\hline 1 & $1.99 \mathrm{~s}$ & 5.1 & + & $3,5,4,2$ \\
\hline 2 & & 80.9 & & \\
\hline 3 & & 65.6 & & \\
\hline 4 & & 79.3 & & \\
\hline 5 & & 71.2 & & \\
\hline 6 & $4.59 \mathrm{~s}$ & 79.2 & + & $3,5,4,8,7$ \\
\hline 7 & & 167.6 & & \\
\hline 8 & $\begin{array}{c}6.23[\mathrm{H}-8, \mathrm{~d}, \mathrm{~J}(8,9)= \\
5.68]\end{array}$ & 127.8 & + & $10,9,7$ \\
\hline 9 & $\begin{array}{c}6.15[\mathrm{H}-9, \mathrm{~d}, \mathrm{~J}(9,8)= \\
5.68]\end{array}$ & 135.7 & + & $10,8,7$ \\
\hline 10 & & 121.5 & & \\
\hline 11 & $\begin{array}{c}2.05-2.22\left[\mathrm{H}^{\mathrm{a}}-11,\right. \\
\left.\mathrm{H}^{\mathrm{b}}-11, \mathrm{~m}\right]\end{array}$ & 35.9 & + & \\
\hline 12 & $\begin{array}{c}2.05-2.31\left[\mathrm{H}^{\mathrm{a}}-12,\right. \\
\left.\mathrm{H}^{\mathrm{b}}-12, \mathrm{~m}\right]\end{array}$ & 24.9 & + & \\
\hline 13 & $\begin{array}{c}4.0-4.21\left[\mathrm{H}^{\mathrm{a}}-13\right. \\
\left.\mathrm{H}^{\mathrm{b}}-13, \mathrm{~m}\right]\end{array}$ & 70.1 & + & 12,10 \\
\hline
\end{tabular}

* ppm from TMS

Isomer II. The ${ }^{1} \mathrm{H}$ NMR spectrum shows two singlet resonances at 1.98 and $4.92 \mathrm{ppm}$, corresponding to $\mathrm{H}-1$ (methyl group) and to H-6 (exocyclic double bond). The H-8 and H-9 protons show a doublet system at $6.68 \mathrm{ppm}(\mathrm{J}$ $=5.9 \mathrm{~Hz})$ and a double-doublet at $6.21 \mathrm{ppm}(\mathrm{J}=5.9$ and $1.71 \mathrm{~Hz})$ respectively. The spectrum also shows multiplet signals at 2.07-2.13, 2.07-2.17 and 3.984.17 , which correspond to the methylenic hydrogens of the heterocyclic ring. The lower field signals can be assigned to $\mathrm{H}-13$ since these hydrogens are on a $\mathrm{C}$ bonded to Oxygen.

The ${ }^{13} \mathrm{C}$ spectrum shows a very high field signal at $5.02 \mathrm{ppm}$, which should correspond to C-1. At lower fields, a signal at d 169.2 is observed, which can be assigned to the highly deshielded C-7 olefinic carbon. Also at downfield it appears a signal at $\mathrm{d} 121.2$ which, based on its intensity, can be assigned to the spiro-type carbon C-10, deshielded by two oxygen atoms.

The complete ${ }^{1} \mathrm{H}$ and ${ }^{13} \mathrm{C}$ NMR chemical shift assignments were deduced from the concerted application of ${ }^{1} \mathrm{H}$-detected "one-bond" and long-range $(\mathrm{C}, \mathrm{H})$ correlation experiments using the HMQC (Heteronuclear Multiple
Quantum Coherence) and HMBC (Heteronuclear Multiple Bond Connectivity) techniques, respectively. ${ }^{12-13}$ By using HMQC analysis, the methyl, methylene and methine signals were assigned. All these $\mathrm{C}-\mathrm{H}$ direct correlations are shown in Table 3. The HMQC spectrum showed correlation between H-1 (d 1.98) with the $\mathrm{C}$ signal at $5.02 \mathrm{ppm}$, and between $\mathrm{H}-6$ (d 4.92) and the $\mathrm{C}$ signal at $80.26 \mathrm{ppm}$. On the other hand, the endocyclic double bond protons, H-8 (6.23 ppm) and $\mathrm{H}-9(6.21 \mathrm{ppm})$ correlate directly with the carbon signals at 126.3 and $136.2 \mathrm{ppm}$, respectively. The methylenic protons, $\mathrm{H}-11, \mathrm{H}-12$ and $\mathrm{H}-13$ correlate with the C signals at $35.89,24.85$ and $70.06 \mathrm{ppm}$, respectively.

With the aim of assigning the resonance values for the quaternary carbons, $\mathrm{C}-2, \mathrm{C}-3, \mathrm{C}-4$ and $\mathrm{C}-5$, as well as to assign unequivocally the olefinic protons at C-8 and C-9, a HMBC analysis was carried out, in order to get information about the long-range correlations existing between $\mathrm{C}$ and $\mathrm{H}$. These results are presented in Table 3.

The HMBC spectrum shows long-range correlations between $\mathrm{H}-6$ and five carbons resonating at 169.2 (C-7), 126.3 (C-8), 76.68, 71.89 and $65.35 \mathrm{ppm}$. According to the intensities of these last three signals in the ${ }^{13} \mathrm{C}$ spectrum, they were assigned to the acetylenic carbons C-4, C-5 and C-3. Since no correlation was found between $\mathrm{H}-6$ and the $\mathrm{C}$ signal at $80.02 \mathrm{ppm}$, this resonance was assigned to $\mathrm{C}-2$ which is farther away from $\mathrm{H}-6$.

Table 3. ${ }^{1} \mathrm{H}$ and ${ }^{13} \mathrm{C}$ NMR of (E) en-yn-dicycloether (Isomer II).

\begin{tabular}{|c|c|c|c|c|}
\hline $\begin{array}{c}\text { Carbon } \\
\mathrm{N}^{\circ}\end{array}$ & $\begin{array}{l}\text { Chemical shift }{ }^{*}, \delta \\
{[\mathrm{H}-\mathrm{X}, \text { multiplicity, J }} \\
(\mathrm{H}, \mathrm{H}) \mathrm{Hz}]\end{array}$ & $\begin{array}{l}{ }^{13} \mathrm{C} \\
(\mathrm{ppm})\end{array}$ & $\begin{array}{l}\mathrm{HMQC} \\
\mathrm{J}(\mathrm{C}, \mathrm{H})\end{array}$ & $\begin{array}{c}\text { Protons } \\
\text { showing } \\
\text { HMBC } \\
\text { correlation } \\
\text { [coupling] } \\
\text { (C-H) }\end{array}$ \\
\hline 1 & $1.98 \mathrm{~s}$ & 5.0 & + & $3,5,4,2$ \\
\hline 2 & & 80.0 & & \\
\hline 3 & & 65.4 & & \\
\hline 4 & & 76.9 & & \\
\hline 5 & & 71.9 & & \\
\hline 6 & $4.92 \mathrm{~s}$ & 80.3 & + & $5,4,8,7$ \\
\hline 7 & & 169.2 & & \\
\hline 8 & $6.68[\mathrm{H}-8, \mathrm{~d}, \mathrm{~J}(8,9)=5.9]$ & 126.3 & + & $10,9,7$ \\
\hline 9 & $\begin{array}{c}6.21[\mathrm{H}-9, \mathrm{dd}, \mathrm{J}(9,8)= \\
5.9, \mathrm{~J}(9,11)=1.71]\end{array}$ & 136.2 & + & $10,8,7$ \\
\hline 10 & & 121.2 & & \\
\hline 11 & $\begin{array}{c}2.07-2.13\left[\mathrm{H}^{\mathrm{a}}-11, \mathrm{H}^{\mathrm{b}}-\right. \\
11, \mathrm{~m}]\end{array}$ & 35.9 & + & 12 \\
\hline 12 & $\begin{array}{c}2.07-2.17\left[\mathrm{H}^{\mathrm{a}}-12, \mathrm{H}^{\mathrm{b}}-\right. \\
12, \mathrm{~m}]\end{array}$ & 24.9 & + & 11 \\
\hline 13 & $\begin{array}{c}3.98-4.17\left[\mathrm{H}^{\mathrm{a}}-13, \mathrm{H}^{\mathrm{b}}-\right. \\
13, \mathrm{~m}]\end{array}$ & 70.1 & + & \\
\hline
\end{tabular}

\section{${ }^{*}$ ppm from TMS}

In order to determine the geometric configuration $(\boldsymbol{E} / \boldsymbol{Z})$ of the exocyclic double bond for Isomers I and II, each compound was analyzed using NOESY (Nuclear Overhausser Spectroscopy)..$^{14-16}$ This technique is based on the dipolar interaction of spins by proton correlation. This correlation depends on the distance between two protons, and normally a NOE signal is observed only if this distance is less than $6 \AA$. If the exocyclic double bond in the en-yndicycloether possesses a $\boldsymbol{Z}$ configuration, then a NOE correlation should be observed between the protons at carbons $\mathrm{C}-6$ and $\mathrm{C}-8$. The results of these experiments indicate that only the Isomer I showed correlation between H-6 and H-8 (Fig. 3), while Isomer II did not show any correlation between those protons. This indicates without any doubt, that Isomer I should correspond to the $(\boldsymbol{Z})$-en-yn-dicycloether, and Isomer II to the $(\boldsymbol{E})$-en-yn-dicycloether. 


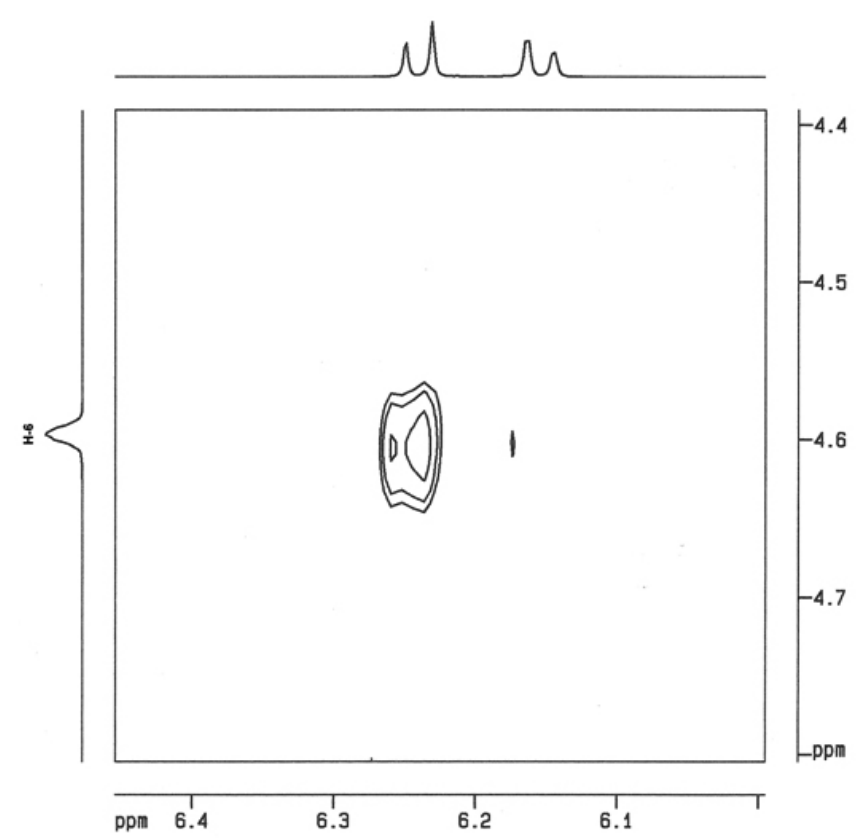

Figure 3. NOESY correlation observed with Isomer I

\section{UV and Infrared Analysis.}

As expected, the infrared spectra of Isomers I and II did not show significant differences (Table 4). In both spectra, the absorption band due to the triple bonds of the acetylenic side chain can be distinguished, at $2139.1 \mathrm{~cm}^{-1}$ for isomer $Z$, and $2137.8 \mathrm{~cm}^{-1}$ for isomer $\boldsymbol{E}$. Also in the spectra, the absorption bands corresponding to the exocyclic double bonds can be observed, at $1627.8 \mathrm{~cm}^{-1}$ for isomer $\boldsymbol{Z}$, and $1633.0 \mathrm{~cm}^{-1}$ for isomer $\boldsymbol{E}$. Other bands worth mentioning are those corresponding to the $\mathrm{C}-\mathrm{O}$ vibrations of the heterocyclic rings, appearing at $1092.9 \mathrm{~cm}^{-1}$ for isomer $\boldsymbol{Z}$ and at $1097.1 \mathrm{~cm}^{-1}$ for isomer $\boldsymbol{E}$.

The UV spectra of both isomers were also determined (Table 4), showing similar absorption profiles as expected. The main absorption band showed a maximum at a wavelentgh of $318 \mathrm{~nm}$ with identical molar absorption coefficients ( $\log \varepsilon$ 3.2). This data was important and was used for the studies of the effects of UV light on the Chamomille extracts and on each of the pure Isomers.

Table 4. Infrared and UV spectroscopic data for en-yn-dicycloethers.

\begin{tabular}{|c|c|c|}
\hline & $\begin{array}{l}\mathrm{IR} \\
\left(\mathrm{cm}^{-1}\right)\end{array}$ & $\begin{array}{c}\text { UV-VIS } \\
\lambda \mathrm{nm}(\log \varepsilon)\end{array}$ \\
\hline Isomer $\boldsymbol{Z}$ & $\begin{array}{c}2139.1 \mathrm{w}(\mathrm{C} \equiv \mathrm{C}) \\
1627.8 \mathrm{~s}(\mathrm{C}=\mathrm{C} \text { exocyclic }) \\
1092.9 \mathrm{~m}(\mathrm{C}-\mathrm{O})\end{array}$ & $\begin{array}{l}212(3.0) \\
228(3.1) \\
318(3.2)\end{array}$ \\
\hline Isomer $\boldsymbol{E}$ & $\begin{array}{c}2137.8 \mathrm{w}(\mathrm{C} \equiv \mathrm{C}) \\
1633.0 \mathrm{~s}(\mathrm{C}=\mathrm{C} \text { exocyclic }) \\
1097.1 \mathrm{~m}(\mathrm{C}-\mathrm{O})\end{array}$ & $\begin{array}{l}212(3.0) \\
228(3.0) \\
318(3.2)\end{array}$ \\
\hline
\end{tabular}

* in methanol

Effect of UV light.

Since ultraviolet light is an important factor influencing the stability of natural pesticides, and therefore limiting its practical application, the effect of UV irradiation on Chamomille extracts and the en-yn-dicycloethers was investigated.

The irradiaton of refined extracts with $300 / 350 \mathrm{~nm}$ light, which was monitored by gas chromatography, revealed that the only compounds noticeably affected by irradiation are the en-yn-dicycloethers. After $5 \mathrm{~min}$ of irradiation the peak corresponding to isomer $\boldsymbol{Z}$ decreased from $35.4 \%$ to $9.18 \%$, while the isomer $\boldsymbol{E}$ peak increased from $6.47 \%$ to $33.58 \%$. In view of these results, which clearly showed that UV irradiation is inducing the isomerization of the dicycloethers, a close monitoring of the irradiation was carried out, analyzing by GC samples taken at 1 min intervals. This experiment showed that a rapid isomerization takes place within the first $5 \mathrm{~min}$ of irradiation. Prolonged irradiation for $25 \mathrm{~min}$ indicated that a photoequilibrium is reached, where the concentrations of the $\boldsymbol{Z}$-isomer and the $\boldsymbol{E}$-isomer are $5.54 \%$ and $38.4 \%$, respectively. This is graphically shown in Fig. 4, where the concentrations of the isomers have been normalized to $100 \%$, so that at the equilibrium the relative $\%$ of the isomers is $12.6 \%$ of $\boldsymbol{Z}$ and $87.4 \%$ of $\boldsymbol{E}$.

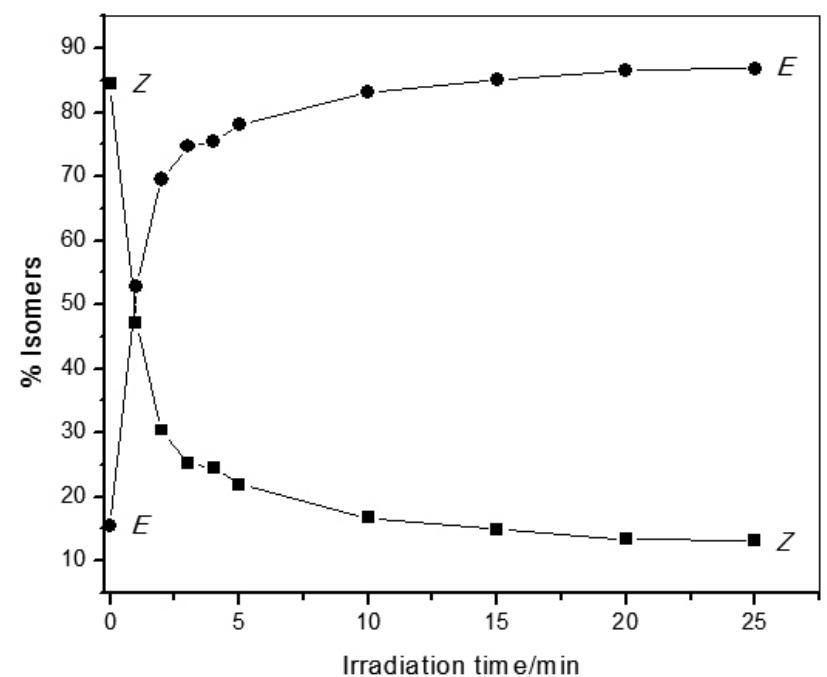

Figure 4. GC monitoring of the effect of irradiation of Chamomille flowers extracts on the composition of $E$ and $Z$ isomers of en-yn-dicycloethers.

In order to further demonstrate the photoisomerization taken place upon irradiation of the Chamomille extract, solutions of the isolated pure isomers were also irradiated under the same conditions. It was found that when the $\boldsymbol{Z}$-isomer is irradiated for $25 \mathrm{~min}$, the $\boldsymbol{Z} / \boldsymbol{E}$ ratio at the equilibrium state is $16.3 / 83.4$. On the other hand, if the $\boldsymbol{E}$-isomer is irradiated under the same conditions, the $\boldsymbol{Z} / \boldsymbol{E}$ ratio at the equilibrium is $25.7 / 74.3$. This shows that a similar $\boldsymbol{Z} / \boldsymbol{E}$ ratio is reached regardless of the starting isomer. This unequivocally demonstrates that when the en-yn-dicycloethers are exposed to UV light, an isomerization of the exocyclic double bonds occurs, and a photoequilibrium is reached favoring the formation of the more stable $\boldsymbol{E}$-isomer.

\section{CONCLUSIONS}

We have successfully isolated the active components of a Chamomille flower extract believed to be responsible for the bioactivity. These compounds, en-yn-dicycloethers, present in both isomeric forms $\boldsymbol{Z}$ and $\boldsymbol{E}$, were characterized and unequivocally identified by spectroscopic techniques. NMR correlation experiments were used to assign the configuration of each isomeric compound. This assignment was confirmed by using NOESY correlation experiments. We also demonstrated that when the en-yn-dicycloethers present in Chamomille extracts are exposed to UV light (and sunlight) a photoisomerization takes place favoring the formation of the more stable $\boldsymbol{E}$-isomer. Preliminary experiments have shown that prolonged irradiation of the Chamomile extracts induced the photodegradation of the active isomers. The results of these studies together with attempts to photostabilize Chamomille extracts will be published elsewhere.

\section{ACKNOWLEDGMENTS}

The authors thank FONDEF Project $\mathrm{N}^{\circ}$ DO3I 1135 for financial support of this work. 


\section{REFERENCES}

1. Mann C., Staba E.J., The chemistry, pharmacology and commercial formulations of Chamomile. In Herbs, Spices and Medicinal Plants. Recent Advances in Botany, Horticulture and Pharmacology; L.E. Craker and J.E. Simon Eds.; Food Products Press, 1986, Vol 1: 235-280.

2. Felklova M., Motl O.; Jasicova M.; Lukes V.; Cesk. Farm. 27, 322, (1978).

3. Gasic O.; Lukic V.; Adamovic D.; Canak N.; Acta Pharm. Hung. 56, 283, (1986).

4. Orav A.; Kailas T.; Ivask K.; Proc. Estonian Acad. Sci. Chem., 50, 39, (2001).

5. Grgesina D.; Mandic M.L.; Karuza L.; Klapec I.; Bockinac D.; Prehrambeno-technol. biotechnol. rev., 33, 111, (1995).

6. Shoukry I.F.; J. Egypt Soc. Parasitol. 27, 893, (1997).

7. Breinlich J.; Scharnagel K.; Arzneimittel-Forschung, 18, 429, (1968).

8. Saavedra V.; Irarrazabal C.R.; Wong M.; Buono-Core G.E.; Vargas R.; Insecticidal Activity of Floral Extracts of Chrysanthemum coronarium (Asteraceae) Against Larvae of Musca domestica L. (Diptera: Muscidae). (to be submitted).
9. Adams R.P., Identification of Essential Oil Components by Gas Chromatography/Mass Spectrometry, $4^{\text {th }}$ Edition, Allured Publishing Corp., 2007.

10. Swingar A.A., Silverstein R.M. Monoterpenes Infrared, Mass, ${ }^{l} H$ NMR and ${ }^{13} C$ NMR Spectra, and Kovats Indices. Aldrich Chemical Co. Milwaukee, WI, 1981.

11. Clark W.; Still Kahn M.; Mitra A.; J. Org. Chem., 43, 2923, (1978).

12. Bax A.; Subramanian S.; J. Magn. Reson., 67, 565, (1986).

13. Bax A.; Summers M.F.; J. Am. Chem. Soc. 108, 2093, (1986).

14. Claridge T.D.W.; High- Resolution NMR Techniques in Organic Chemistry, Pergamon Press, London, 1999.

15. Annual Reports on NMR Spectroscopy, Vol. 63, Graham A. Webb (Editor), Academic Press, 2008

16. Neuhaus D.; Williamson M.P., The Nuclear Overhauser Effect in Structural and Conformational Analysis, 2nd Ed., Wiley-VCH, 2000.

17. Silverstein R.M.; Webster F.X.; Kiemle D.; Spectrometric Identification of Organic Compounds, $7^{\text {th }}$ Ed., Wiley, 2005. 